\title{
Kot domowy jako model badawczy w procedurach wspomaganego rozrodu dzikich kotowatych
}

\section{dr n. wet. Natalia Sowińska ${ }^{\bowtie}$}

Pracownia Rozrodu Zwierząt, Katedra Genetyki i Podstaw Hodowli Zwierząt (WZGH), Wydział Medycyny Weterynaryjnej i Nauk o Zwierzętach, Uniwersytet Przyrodniczy w Poznaniu

https://doi.org/10.18388/pb.2021_416

$\bowtie$ autor korespondujący: natalia.sowinska@ up.poznan.pl

Słowa kluczowe: biotechniki, zapłodnienie in vitro, przenoszenie zarodków, kriokonserwacja, oocyty, zarodki

Wykaz stosowanych skrótów: AI (ang. artificial insemination) - sztuczne unasienianie; ART (ang. assisted reproductive techniques) - procedury wspomaganego rozrodu; COC (ang. cumulus oocyte complex) - kompleksy oocyt-kumulus; ET (ang. embryo transfer) - przenoszenie zarodków; FSH (ang. follicle-stimulating hormone) - hormon folikulotropowy; hCG (ang. human chorionic gonadotropin) - ludzka gonadotropina kosmówkowa; ICSI (ang. intracytoplasmic sperm injection) - iniekcję plemnika do cytoplazmy; IVC (ang. in vitro culture) - hodowla zarodków in vitro; IVF (ang. in vitro fertilization) - zapłodnienie pozaustrojowe; IVM (ang. in vitro maturation) - dojrzewanie pozaustrojowe

\section{STRESZCZENIE}

$\mathbf{P}$

rocedury wspomaganego rozrodu (ART) są istotną częścią programów ratowania ginących gatunków. Wszystkie gatunki dzikich kotowatych są zagrożone wyginięciem, a kot domowy jest dobrym i łatwo dostępnym modelem do badań nad kotowatymi. Do procedur ART stosowanych u kota i dzikich kotowatych należą sztuczne unasienianie, dojrzewanie i zapłodnienie oocytów in vitro metodą IVF i ICSI, hodowla zarodków, przenoszenie zarodków, kriokonserwacja nasienia, oocytów i zarodków. Skuteczność poszczególnych procedur u kotów i kotowatych jest często dużo niższa niż w przypadku człowieka, zwierząt gospodarskich lub laboratoryjnych, ale dotychczasowe sukcesy potwierdzają potrzebę prowadzenia dalszych badań.

\section{WSTĘP}

Pomimo, że techniczne aspekty procedur wspomaganego rozrodu (ang. assisted reproductive techniques, ART) są bardzo podobne u ludzi i zwierząt, ich stosowaniu przyświecają skrajnie różne cele. W przypadku ludzi głównym celem jest uzyskiwanie potomstwa przez pary doświadczające zaburzeń płodności, co oznacza korzyści indywidualnych pacjentów. U zwierząt gospodarskich procedury ART są częścią programów hodowlanych danego gatunku, czy typu użytkowego i zmierzają do uzyskania większej liczby potomstwa od genetycznie cennych osobników, a przez to korzyści dla hodowców [1]. Trzecią grupą są zagrożone wyginięciem dzikie zwierzęta. W przypadku programów ochrony gatunkowej, uogólnione korzyści z zastosowania procedur ART są trudne do zaklasyfikowania do jednej z wyżej wymienionych kategorii. Beneficjentami tych programów są zarówno ludzie, jak i zwierzęta, i to nie tylko te, które bezpośrednio podlegają procedurom. W programach ochrony gatunkowej zwierzęta udomowione stanowią często modele badawcze dla gatunków dzikich i zagrożonych.

\section{ROLA BIOTECHNIK ROZRODU W OCHRONIE DZIKICH GATUNKÓW}

Wymieranie gatunków jest częścią naturalnego procesu ewolucji i jest nieodwracalne [2]. Działania człowieka, takie jak niszczenie siedlisk (poprzez stosowanie ekspansywnej gospodarki rolnej i wylesianie), nadmierne polowania lub kłusownictwo, a także zanieczyszczanie środowiska doprowadziły do znacznie wyższego tempa wymierania gatunków zwierząt $w$ stosunku do tempa specjacji, czyli powstawania nowych gatunków. Według Czerwonej Listy Zagrożonych Gatunków prowadzonej przez Międzynarodową Unię Ochrony Przyrody jeden na cztery gatunki ssaków i jeden na osiem gatunków ptaków są zagrożone wyginięciem, podobnie jak jedna trzecia płazów i połowa wszystkich żółwi [3]. Celem ochrony przyrody jest zachowanie bioróżnorodności, ponieważ wyginięcie pojedynczego gatunku może wpłynąć na funkcjonowanie globalnego ekosystemu $[2,4]$.

Standardową strategią zachowania zmienności genetycznej, a tym samym zdolności reprodukcyjnej, jest ochrona i zachowanie siedlisk [5]. Wiadomo, że kurczenie się zasobów pożywienia, przestrzeni życiowej do wychowania potomstwa lub znalezienia niespokrewnionego partnera przyczyniają się istotnie do ograniczania bioróżnorodności. Konsekwencją zawężania puli genowej poprzez kojarzenia w pokrewieństwie może być tzw. depresja inbredowa. Jej objawami są wysoka śmiertelności noworodków i młodych osobników, wady wrodzone oraz nieprawidłowości związane z układem rozrodczym i rozrodem, takie jak wnętrostwo, obniżenie jakości nasienia, ograniczenie zdolności do zapłodnienia, a także wrodzone wady serca, niedobory immunologiczne i zwiększona podatność na zmiany środowiskowe [5-7]. Wszystkie te czynniki są szczególnie niebezpieczne i obecnie znacząco zagrażają stabilności wielu populacji dzikich 
zwierząt. Z tego powodu utrzymanie różnorodności genetycznej jest głównym celem badań dotyczących rozrodu dzikich zwierząt z wykorzystaniem ART. Ponadto, podobnie jak u zwierząt gospodarskich, wspomagany rozród daje możliwość pozyskania znacznie większej liczby potomstwa $\mathrm{w}$ porównaniu $\mathrm{z}$ rozrodem naturalnym, co w przypadku zagrożonych gatunków może mieć kluczowe znaczenie dla programów ich ochrony. Procedury ART są szczególnie przydatne $\mathrm{w}$ odniesieniu do zwierząt, które:

(i) nie rozmnażają się w sposób naturalny,

(ii) nieoczekiwanie umierają,

(iii) są zbyt stare, aby rozmnażać się w sposób naturalny, ale są cenne pod względem genetycznym lub

(iv) żyją w odległych miejscach $[5,8]$.

Warto wspomnieć, że dzięki procedurom ART udało się zwiększyć lub uratować populacje wielu gatunków dzikich zwierząt [9-11]. Doskonałym przykładem jest populacja pandy wielkiej (Ailuropoda melanoleuca), która zwiększyła się blisko trzykrotnie (1996 - 104 osobniki, 2008 - 271 osobników) dzięki współpracy naukowców ze Smithsonian Institut w Waszyngtonie (USA) i ośrodków ochrony w Chińskiej Republice Ludowej. Lata badań podstawowych z zakresu biologii rozrodu, a następnie wykorzystanie techniki sztucznego unasieniania (ang. artificial insemination, AI) przy użyciu nasienia świeżego i kriokonserwowanego, doprowadziło do potrojenia liczby osobników populacji żyjącej w niewoli. Obecnie w chińskich ośrodkach hodowlanych rodzi się rocznie od 25 do 30 młodych, co potwierdza sukces projektu [10].

\section{ROLA BIOTECHNIKI ROZRODU W OCHRONIE ZAGROŻONYCH KOTOWATYCH}

Dzikie kotowate należą do najbardziej zagrożonych biologicznie taksonów na ziemi [12]. Wszystkie 38 gatunków dzikich kotowatych znajduje się na Czerwonej Liście Międzynarodowej Unii Ochrony Przyrody, a liczebności populacji 29 gatunków ma tendencję spadkową [3]. Utrata siedlisk oraz zasobów jest główną przyczyną dramatycznej sytuacji rodziny Felidae [12,13]. Zabijanie w celu pozyskania futer oraz fragmentów ciała zwierząt, które wciąż są stosowane w tradycyjnej medycynie orientalnej są również wymieniane jako istotne czynniki spadku wielkości populacji niektórych gatunków [14,15]. Podobnie jak w przypadku innych ssaków, jednym z największych problemów w nieudomowionych populacjach kotów jest ograniczona pula genowa.

Procedury ART obejmujące sztuczne unasienianie, zapłodnienie in vitro (ang. in vitro fertilization, IVF), iniekcje plemnika do cytoplazmy (ang. intracytoplasmic sperm injection, ICSI), hodowlę zarodków in vitro (ang. in vitro culture, IVC), przenoszenie zarodków (ang. embryo transfer, ET) oraz kriokonserwację gamet i zarodków mają obecnie duże zastosowanie w programach ochrony kotowatych. Istnieje wiele korzyści stosowania procedur ART także dla kotowatych. Po pierwsze, techniki te można wykorzystać do rozmnażania osobników, u których naturalne krycie jest niemożliwe (np. z powodu wzajemnej agresji) lub w przypadku zwierząt żyjących w odległych geograficznie populacjach, co jest szczególnie istotne z punktu widzenia depresji inbredowej [12]. Ponadto, skuteczna kriokonserwacja gamet i zarodków pozwala na długoterminowe przechowywanie i ochronę różnorodności genetycznej oraz zabezpiecza przed skutkami ewentualnych epidemii czy klęsk żywiołowych. Wspomagany rozród można również wykorzystać w programach hodowlanych do wprowadzania „świeżego” materiału genetycznego do populacji żyjącej $\mathrm{w}$ niewoli bez konieczności odławiania dzikich zwierząt [12,16-19]. Ponadto, kriokonserwacja zarodków wydłuża czas niezbędny do doboru odpowiednich matek zastępczych, zwiększając prawdopodobieństwo pomyślnej ciąży i porod.

\section{KOT DOMOWY JAKO MODEL DLA DZIKICH KOTOWATYCH}

Wiadomo, że skuteczność wspomaganego rozrodu jest pochodną wiedzy z zakresu biologii rozrodu danego gatunku lub gatunków spokrewnionych [16]. W przypadku dzikich kotowatych, najbardziej odpowiednim, fizjologicznie porównywalnym i łatwym do uzyskania modelem biomedycznym jest kot domowy (Felis catus) $[17,20,21]$. Badania prowadzone na modelu kota domowego pomagają poszerzyć wiedzę na temat biologii rozrodu kotów. Ponadto wykazano, że protokoły opracowane dla kota domowego mogą być $\mathrm{z}$ powodzeniem stosowane dla nieudomowionych kotów [13].

Kot domowy jest nie tylko modelem biomedycznym w badaniach nad rozrodem dzikich kotów. Jest także z sukcesem wykorzystywany jako model badawczy dla co najmniej 18 dziedzicznych chorób człowieka, od zaburzeń metabolicznych, takich jak mukopolisacharydoza [22,23] i porfiria [24] po nieprawidłowości chromosomalne, takie jak zespół Klinefeltera [25]. Procedury ART pozwalają na precyzyjne planowanie doświadczeń, w tym ciąż i wielkości miotów $[12,26]$.

\section{OSIAGNIECIA W ZAKRESIE BIOTECHNIK ROZRODU KOTÓW I KOTOWATYCH}

Koniec XIX i początek XX wieku wiążą się z ogromnymi postępami badań nad wspomaganym rozrodem. Pierwsze doniesienie o udanym przeniesieniu zarodka króliczego do macicy innego królika opublikował Walter Heape w 1891 roku [27]. W tamtym okresie zainteresowanie ochroną przyrody było jednak znikome. Dopiero 90 lat później, Schriver i Kraemer opisali pierwsze przeniesienie zarodka kota domowego [28]. Kolejne 10 lat minęło do urodzenia pierwszych kociąt po zapłodnieniu in vitro [29]. W tym samym roku Dresser i wsp. donieśli o udanej kriokonserwacji zarodków kota, które zostały przeniesione do samicy-biorczyni [30]. Od tamtego czasu opisano wiele skutecznych procedur oraz protokołów ART stosowanych u kotów i dzikich kotowatych. W ostatnich latach obserwuje się na świecie i w Polsce szczególny wzrost zainteresowania naukowego zagadnieniami związanymi z rozrodem kotów [31,32]. Wciąż jednak wiele procedur pozostaje na poziomie eksperymentalnym i wymaga licznych badań.

\section{SZTUCZNE UNASIENIANIE (AI)}

Sztuczne unasienianie jest techniką polegającą na wprowadzeniu nasienia samca do dróg rodnych samicy z pomi- 

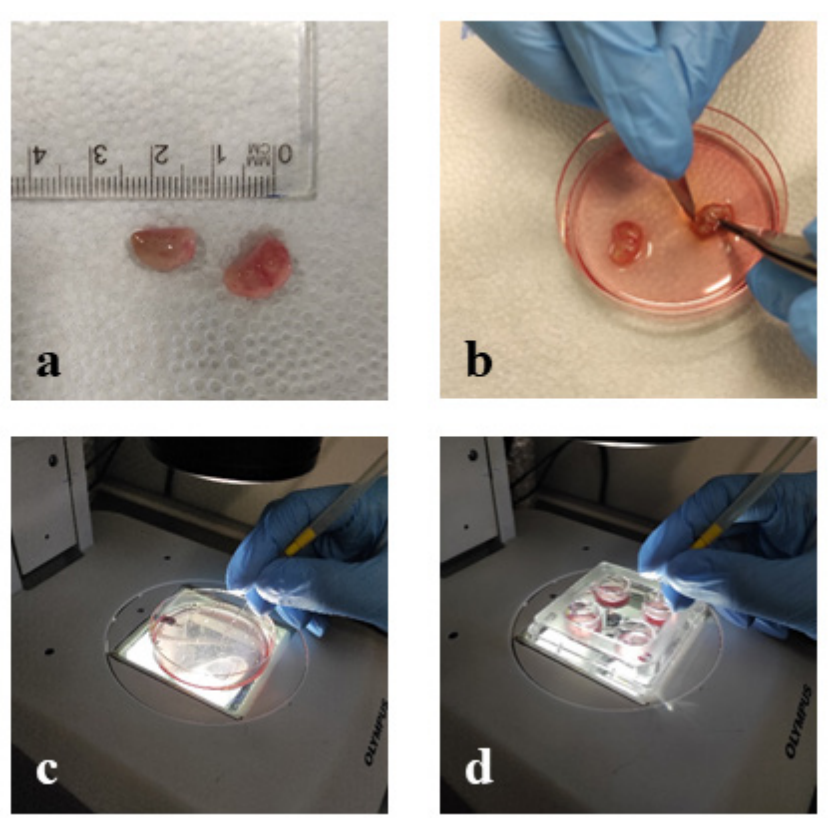

Rycina 1. Procedura pozyskiwania oocytów kota domowego: (a) jajniki usunięte $\mathrm{w}$ trakcie rutynowego zabiegu ovariohisterectomii, (b) nacinanie kory jajnika skalpelem, (c) wyszukiwanie oocytów spełniających, (d) przenoszenie wyselekcjonowanych oocytów do płytki 4-dołkowej z pożywką do IVM.

nięciem stosunku płciowego. U zwierząt domowych opisano różne techniki AI, do najczęściej stosowanych należą unasienianie dopochwowe, domaciczne lub do jajowodu. Do zabiegu AI może być użyte zarówno nasienie świeże, jak i poddane kriokonserwacji. Pierwsze zabiegi AI kota domowego przeprowadzono ponad 40 lat temu [33]. Niestety nadal nie jest to technika powszechnie stosowana zarówno w przypadku kota domowego, jak i dzikich kotowatych. Wynika to z licznych ograniczeń natury anatomicznej i fizjologicznej rodziny Felidae. Pierwszym ograniczeniem sztucznego unasieniania kotowatych jest występowanie $\mathrm{u}$ większości gatunków owulacji prowokowanej. Nadal nie udało się opracować skutecznych protokołów stymulacji hormonalnej większości gatunków dzikich kotowatych co istotnie ogranicza możliwość zastosowania AI [34]. Ponadto, ejakulat kocura ma stosunkowo małą objętość i niską koncentrację plemników co sprawia, że unasienianie dopochwowe, dość łatwe w wykonaniu, jest zazwyczaj nieskuteczne [35]. Unasienianie domaciczne $\mathrm{z}$ zastosowaniem kateteru jest technicznie bardzo trudne ze względu na długą, sztywną i bardzo wąską szyjkę macicy kotek [33]. Od kilku lat coraz bardziej powszechne staje się AI z zastosowaniem endoskopii sztywnej (metoda TCI, ang. trans cervical insemination), które daje spore nadzieje na rozwój tej techniki wspomaganego rozrodu kotowatych [36,37]. W przypadku dzikich kotowatych opisano także kilka skutecznych zabiegów AI metodą laparotomii (czyli po otwarciu jamy brzusznej), ale ze względu na duże ryzyko związane z zabiegiem operacyjnym i konieczność wykonania zabiegu w warunkach czystości chirurgicznej (co skutecznie ogranicza zastosowanie tej metody w warunkach terenowych, w tym także w ogrodzie zoologicznym) metoda ta nie jest powszechnie stosowana i nie wiąże się z nią wielkich nadziei [9,38]. Pewne oczekiwania wiąże się natomiast $\mathrm{z}$ inseminacją dojajowodową metodą laparoskopii. Opisane niedawno wyniki są bardzo korzystne, należy jednak pamiętać, że ze wzglę-
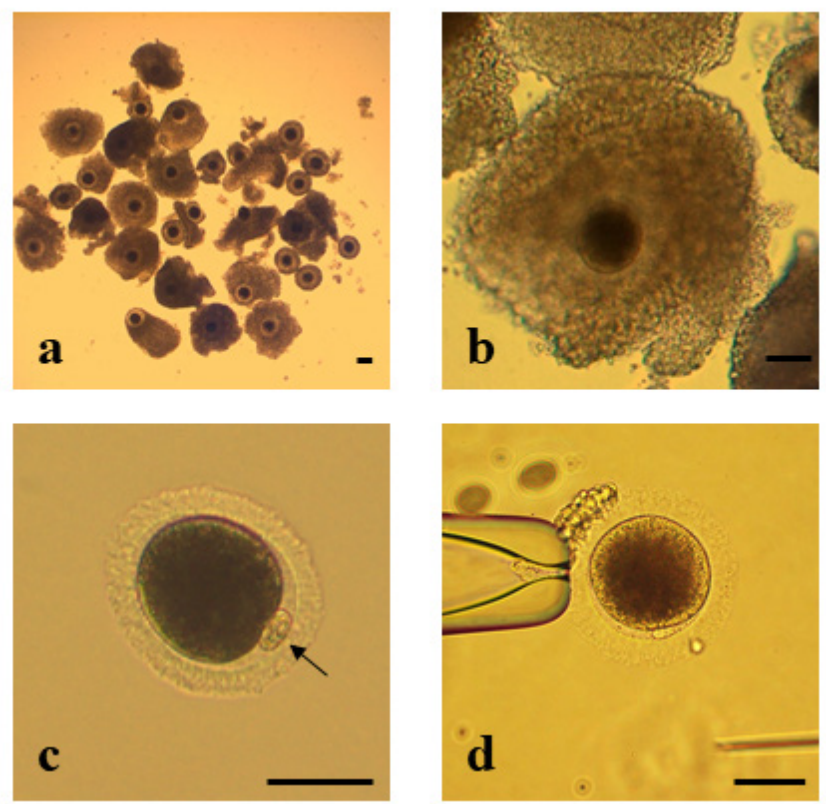

Rycina 2. Oocyty kota domowego: $(a, b)$ niedojrzałe oocyty I klasy charakteryzują się ciemną, homogenną się ciemną, homogenna ooplazmą i obecnością wielu warstw komórek wzgórka jajonośnego; (c) oocyty, które przeszły proces dojrzewania i osiągnęy stadium metafazy II podziału mejotycznego z widocznym ciałkiem kierunkowym (czarna strzałka), (d) w trakcie iniekcji plemnika do cytoplazmy (ICSI) oocyt jest przytrzymywany przy użyciu mikromanipulatora. Czarna linia reprezentuje $50 \mu \mathrm{m}$.

du na niewielki rozmiar kocich jajowodów metoda ta jest bardzo trudna do wykonania pod względem technicznym i wymaga dużego doświadczenia od prowadzącego zabieg lekarza weterynarii [39].

\section{SELEKCJA KOMPLEKSÓW OOCYT-CUMULUS (COC) ORAZ DOJRZEWANIE IN VITRO (IVM)}

Pozyskiwanie COC (ang. cumulus oocyte complex) o odpowiednim potencjale rozwojowym jest kluczowym elementem dojrzewania pozaustrojowego. W przypadku kota domowego COC pozyskiwane są z jajników usuniętych $\mathrm{w}$ trakcie rutynowych zabiegów kastracji chirurgicznej (ovariohisterectomii) (Ryc. 1a). Najczęściej stosowaną metodą pozyskiwania COC jest wielokrotne nacinanie skalpelem kory jajnika (Ryc. 1b) [40]. Podobną technikę stosuje się u dzikich kotowatych [12]. Kolejnym istotnym etapem procedury jest selekcja COC pod mikroskopem stereoskopowym (Ryc. 1c), a następnie przeniesienie do pożywki z dodatkiem gonadotropin (Ryc. 1d). Obecnie powszechnie stosuje się klasyfikację zaproponowaną przez Wood'a i wsp. [41]. Dzieli ona kompleksy na 4 klasy w zależności od zabarwienia i granulacji cytoplazmy, liczby warstw komórek wzgórka jajonośnego oraz jakości osłonki przejrzystej. Najbardziej pożądane są COC I klasy, które charakteryzują się ciemną, homogenna ooplazmą i obecnością wielu warstw komórek wzgórka jajonośnego (Ryc. 2a i 2b). Badania wykazały, że COC I klasy wykazują wyższy potencjał dojrzewania i zapłodnienia in vitro niż COC niższych klas [42]. Oocyty kota domowego poddawane są inkubacji w pożywkach IVM w określonych warunkach gazowych. Najczęściej stosuje się atmosferę 5\% $\mathrm{CO}_{2} \mathrm{w}$ powietrzu lub mieszaninę $90 \% \mathrm{~N}_{2}, 5 \%$ $\mathrm{CO}_{2}$ i $5 \% \mathrm{O}_{2}$ [13]. Dojrzewanie in vitro COC kota domowego 

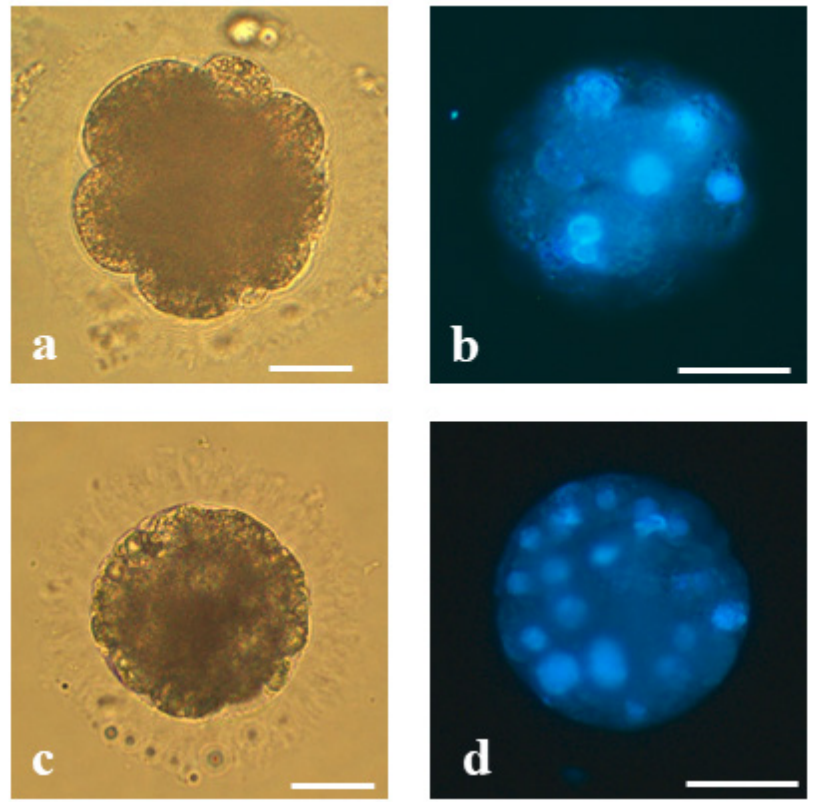

Rycina 3. Zarodki kota domowego uzyskane po zapłodnieniu metodą ICSI: (a, b) zarodek w stadium 6-8 blastomerów, (c, d) zarodek w stadium moruli. Zdjęcia wykonano pod mikroskopem odwróconym $(\mathrm{a}, \mathrm{c})$ oraz pod mikroskopem epifluorescencyjnym po zabarwieniu barwnikiem Hoechst 33342. Czarna linia reprezentuje $100 \mu \mathrm{m}$.

trwa 24 godziny [40]. Skuteczność tego procesu jest niższa niż w przypadku człowieka oraz wielu gatunków zwierząt i wynosi około 50-70\% (Ryc. 2c) [43,44].

\section{ZAPŁODNIENIE POZAUSTROJOWE ORAZ HODOWLA ZARODKÓW}

Spośród technik zapłodnienia pozaustrojowego najpowszechniejsze u kota domowego są klasyczne zapłodnienie in vitro (IVF), czyli ko-inkubacja gamet oraz iniekcja plemnika do cytoplazmy oocytu (ICSI).

Pierwsze pozaustrojowe zapłodnienie kota domowego miało miejsce w 1988 [45]. Klasyczna technika IVF polega na wspólnej inkubacji dojrzałych oocytów z plemnikami. Jest prosta i nie wymaga drogiego sprzętu, a współczynnik zapłodnienia (\% dzielących się zygot) wynosi 30-50\% [31,43]. Technika ICSI polega na iniekcji plemnika bezpośrednio do cytoplazmy oocytu przy użyciu mikromanipulatora (Ryc. 2d). W 1998 roku Pope i wsp. jako pierwsi potwierdzili ICSI jako skuteczną metodę zapłodnienia oocytów kota domowego poprzez narodziny żywego kociaka [46]. Od tamtego czasu metoda ta stała się bardziej powszechna, a uzyskiwany odsetek dzielących się zygot znacznie wzrósł i wynosi 50-80\% [47].

W większości badań współczynnik zapłodnienia waha się od $40 \%$ do $80 \%$, w zależności od metody zapłodnienia, warunków hodowli i użytego nasienia (świeżego lub kriokonserwowanego) (Ryc. 3a i 3b) $[44,48,49]$. Niestety wiele zarodków pozyskanych in vitro zatrzymuje swój rozwój w stadium wczesnej moruli ( $\geq 16$ blastomerów) (Ryc. 3c i 3 d), a maksymalnie 30-40\% dzielących się zarodków osiąga stadium blastocysty. Przyjmując jednak za punkt wyjścia do obliczeń liczbę oocytów poddanych zapłodnieniu, szansa
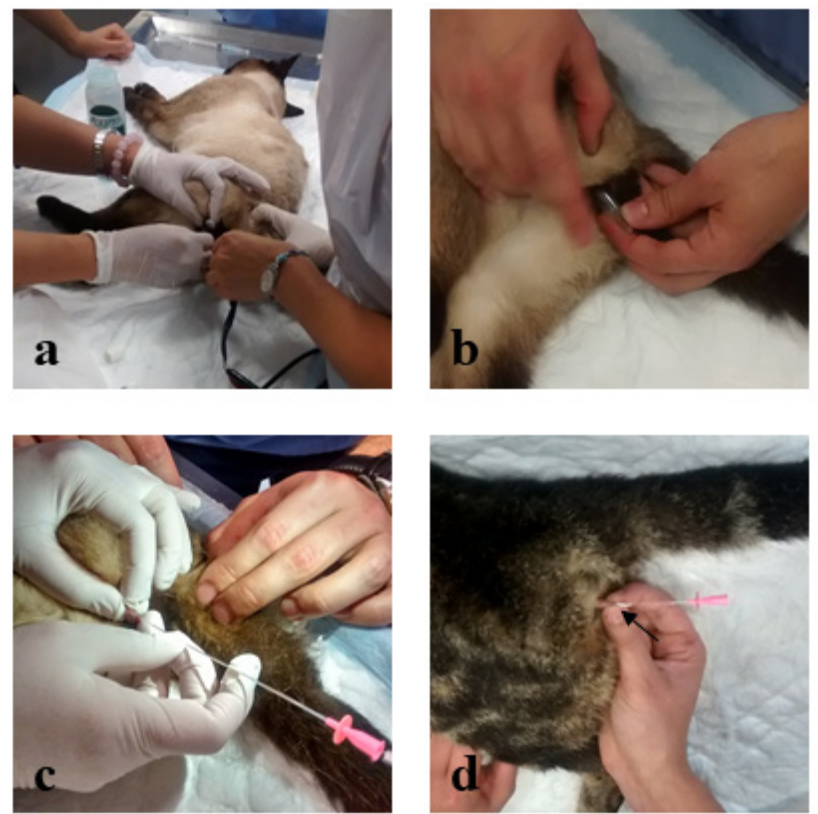

Rycina 4. Pobieranie nasienia od kota domowego metodą elektroejakulacji (a, b) oraz kateteryzacji cewki moczowej (c, d). (a) Wprowadzanie elektrody do prostnicy kota, (b) zbieranie nasienia do probówki. (c) Wprowadzanie cewnika do cewki moczowej kota, (d) wyjęcie cewnika z widocznym nasieniem (czarna strzałka).

na osiągnięcie stadium blastocysty in vitro wynosi ok $20 \%$. Efektywność pozyskiwania blastocyst kota domowego jest nadal niezadawalająca i niższa od średniego \% blastocyst uzyskiwanego in vitro np. u bydła (30-40\%).

Istotna redukcja odsetka zarodków rozwijających się w warunkach in vitro wiąże się m.in. z występowaniem tzw. bloku rozwojowego w stadium odpowiadającym uruchomieniu genomu zarodka (EGA) danego gatunku. U kota domowego ma to miejsce w stadium 5-8 blastomerów [50], a u bydła 8-16 blastomerów [51].

Badania prowadzone w celu pokonania bloku w stadium wczesnej moruli wykazały, że chronologia rozwoju zarodka kota in vitro i in vivo jest podobna do tego stadium [52]. Dotychczasowe badania mające na celu podniesienie odsetka uzyskiwanych blastocyst, polegające na modyfikacji składu pożywek, źródeł białka, atmosfery gazowej, temperatury, a także na wspólnej hodowli zarodków z komórkami somatycznymi nie przyniosły oczekiwanych rezultatów $[38,53,54]$.

\section{POZYSKIWANIE NASIENIA}

Pozyskiwanie nasienia jest kluczowym elementem wspomaganego rozrodu. Nasienie świeże lub poddane kriokonserwacji może być zastosowane zarówno do sztucznego unasieniania jak i zapłodnienia pozaustrojowego metodac IVF lub ICSI. Opisano 4 techniki pozyskiwania nasienia od kotów i dzikich kotowatych: elektroejakulacja, pobieranie na sztuczną pochwę, pozyskiwanie nasienia z najądrzy i kateteryzacja cewki moczowej. Elektroejakulacja jest metodą wymagająca specjalistycznego sprzętu i wymaga pełnego znieczulenia. Technika ta polega na wywoływaniu ejakulacji pod wpływem impulsów prądu elektrycznego z wpro- 

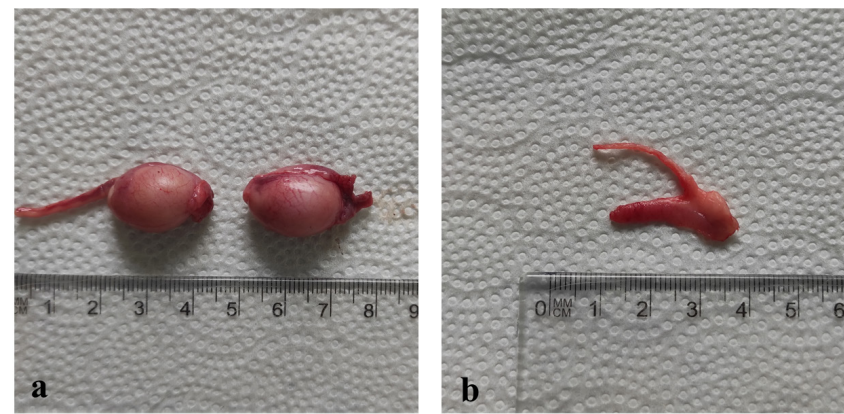

Rycina 5. Zabieg kastracji. (a) Jądra kota domowego usunięte w trakcie zabiegu kastracji; (b) najądrza kota domowego odpreparowane od jąder przed pozyskiwaniem nasienia poprzez nacinanie.

wadzonej do odbytu elektrody (Ryc. 4a i 4b). Przez niektórych autorów uważana jest za metodę kontrowersyjną pod względem etycznym. Pobieranie przy użyciu sztucznej pochwy jest trudne do wykonania i wymaga obecności samicy w rui, która pełni rolę prowokatorki [55]. Istotny jest także fakt, że metoda ta nie może być stosowana w przypadku kotów nieudomowionych [31]. Kolejna metoda została opracowana kilka lat temu przez zespół Zambelli i wsp. i polega na pobieraniu nasienia poprzez kateteryzację cewki moczowej [56]. Kotu podaje się lek znieczulający - medetomidynę, który jest rutynowo stosowany $\mathrm{w}$ anestezjologii weterynaryjnej. Medetomidyna poza działaniem uspokajającym i przeciwbólowym ma także działanie a-adrenergiczne powodujące skurcz mięśni gładkich przewodów wyprowadzających nasienie, a tym samym uwolnienie pozajądrowych zasobów plemników [31,56]. Następnie do cewki moczowej wprowadzany jest cewnik, do którego w wyniku działania siły kapilarnej przenika nasienie (Ryc. 4c i 4d). Pobrany w ten sposób ejakulat ma niewielką objętość, ale ma wysoką koncentracje plemników. Metoda ta zdecydowanie zrewolucjonizowała wspomagany rozród kota domowego oraz kotowatych i obecnie jest $\mathrm{z}$ powodzeniem stosowana $\mathrm{w}$ większości ośrodków [57]. Czwarta technika to pozyskiwanie nasienia najądrzowego. Ma ona zastosowanie $\mathrm{w}$ przypadku jąder, które zostały usunięte i polega na wielokrotnym nacinaniu ogonów najądrzy skalpelem, zanurzeniu tkanki w medium zoptymalizowanym dla plemników, np. $\mathrm{w}$ rozrzedzaniu opartym na buforze TRIS lub soli fizjologicznej, a następnie przepłukaniu poprzez wirowanie frakcjonujące (Ryc. 5a i 5b) [31,43,55,58]. Technika ta jest prosta w wykonaniu i może być zastosowana w przypadku wartościowego genetycznie samca (zarówno kota domowego jaki i nieudomowionego), który został poddany kastracji lub niespodziewane umarł.

PRZENOSZENIE ZARODKÓW (ANG. EMBRYO TRANSFER, ET)

Przenoszenie zarodków to technika polegająca na umieszczeniu zarodka $\mathrm{w}$ stadium moruli lub blastocysty $\mathrm{w}$ układzie rodnym matki zastępczej. Dotychczas opisano zabiegi ET zarówno u kota domowego, jak i wielu gatunków dzikich kotowatych $[59,60]$. Do tej pory urodziły się kocięta tygrysów, gepardów, pum, ocelotów, manuli stepowych, ocelotów tygrysich, ocelotów argentyńskich i in. [12,61,62]. Pierwsze zabiegi ET polegały na wykonaniu laparotomii, czyli otwarcia jamy brzusznej i przeniesieniu zarodka bezpośrednio do macicy. Od kilku lat coraz częściej przenosi się zarodki bezpośrednio do jajowodu, przy użyciu laparoskopii, czyli wziernikowania jamy brzusznej za pomocą instrumentu optycznego. Technika ta jest niewątpliwie mniej traumatyczna i nie wiąże się z ryzykiem zrostu brzusznego, dzięki czemu może być stosowana wielokrotnie u jednego osobnika [12]. Warto wspomnieć, że kot domowy, oprócz bycia modelem biomedycznym do badań na dzikimi kotowatymi jest również wykorzystywany jako biorca zarodków dzikich kotowatych w procedurze tzw. międzygatunkowego ET. Dotychczas udało się uzyskać tą metodą kocięta indyjskiego kota pustynnego i afrykańskiego dzikiego kota po przeniesieniu odpowiednio 14 i 8 zarodków do poddanych synchronizacji hormonalnej kotek domowych. Protokół synchronizacji zakładał podawanie hormonu folikulotropowego (FSH) w dawkach wzrastających (1-6 mg) 1 $x$ dziennie przez 4 dni, a następnie 100 IU ludzkiej gonadotropiny kosmówkowej (hCG) 5-go dnia [48].

\section{KRIOKONSERWACJA}

Kriokonserwacja jest metodą mającą na celu utrzymanie żywotności komórek, tkanek lub narządów poprzez przechowywanie ich $\mathrm{w}$ ekstremalnie niskich temperaturach. U kotów stosuje się obecnie dwie metody kriokonserwacji gamet i zarodków: powolne zamrażanie i witryfikację [18]. W 1988 Dresser i wsp. [46] przeprowadzili pierwsze udane przeniesienie kriokonserwowanych zarodków pozyskanych in vivo, a w 1994 Pope i wsp. [63] poinformował o narodzinach żywych kociąt po ET kriokonserwowanych zarodków pozyskanych in vitro. Od tego czasu uzyskano kilka prawidłowych ciąż zakończonych urodzeniem żywych kociąt po przeniesieniu kriokonserwowanych zarodków zarówno kotów domowych, jak i dzikich [64-66]. Ponieważ produkcja zarodków in vitro jest skomplikowaną procedurą, wymagającą specjalnie wyposażonego laboratorium oraz dostępności gamet zarówno żeńskich, jak i męskich, kriokonserwacja zarodków jest ważnym narzędziem w programach wspomaganego rozrodu ponieważ umożliwia czasowe rozdzielenie uzyskania zarodka i jego przeniesienia, dając tym samym większą szanse na znalezienie odpowiedniej matki zastępczej.

Pierwsze doniesienie o kriokonserwacji kocich oocytów zostało opublikowane przez Luvoni w 1997 roku i wskazywało na wyższość metody powolnego zamrażania oocytów [67]. Z kolei w 2012 roku opisano narodziny pierwszych kociąt uzyskanych z witryfikowanych oocytów [68]. Mimo wielkiego sukcesu jakim jest urodzenie żywych kociąt pochodzących z kriokonserwowanych oocytów, nadal skuteczność tej procedury, w porównaniu z jej skutecznością u człowieka, bydła czy myszy, jest bardzo niska. Jak dotąd nie opublikowano powtarzalnej metody kriokonserwacji oocytów kota. W nielicznych pracach odsetek dzielących się zygot uzyskanych z witryfikowanych oocytów wahał się od $14 \%$ do $25 \%$ [47,69-71], a odsetek uzyskiwanych blastocyst wynosił od 1,5\% do 7,5\% [71-73] dlatego kriokonserwacja kocich oocytów jest nadal uważana za technikę eksperymentalną. Należy zaznaczyć, że oocyty kota domowego są trudnym materiałem do kriokonserwacji. Charakteryzuje je bardzo ciemna i homogenna ooplazma, co najprawdopo- 
dobniej wynika z wysokiej zawartości lipidów [74]. Obecność wysokiej zawartości wewnątrzkomórkowych lipidów utrudnia przenikanie krioprotektantów do oocytu oraz powoduje nierównomierne zamrażanie skutkujące niską efektywnością tego procesu. Ponadto, w niedojrzałych oocytach kota występuje stosunkowo duży pęcherzyk zarodkowy w porównaniu z innymi gatunkami ssaków. Natomiast ograniczona przeżywalność dojrzałych oocytów wynika z otoczki jądrowej i obecności wrzeciona kariokinetycznego drugiego podziału mejotycznego [40].

Efektywność kriokonserwacji nasienia kota jest również niższa $\mathrm{w}$ porównaniu $\mathrm{z}$ innymi gatunkami np. bydłem czy psem domowym. Pomimo prowadzenia szerokiego frontu badań [75], niezadawalające wyniki kriokonserwacji plemników kocura wiążą się z licznymi utrudnieniami np. wysoka częstość teratozoospermii ( $\geq 60 \%$ plemników z nieprawidłową budową) [6] czy duża wrażliwość plemników na zmiany osmotyczne powodujące utratę ruchliwości lub uszkodzenia błony komórkowej [21].

\section{ZNACZENIE BADAŃ PODSTAWOWYCH WSPOMAGANEGO ROZRODU KOTA DOMOWEGO}

Wszystkie procedury ART stosowane dotychczas u dzikich kotów zostały opracowane na modelu kota domowego. Przydatność tych procedur dla utrzymania populacji dzikich kotów jest bezpośrednio związana z podstawową wiedzą o ich biologii. Ze względu na oczywiste utrudnienia ze zdobywaniem tej wiedzy, model kota domowego jest szczególnie cenny. Zadawalające wyniki uzyskiwane po aplikacji procedur ART w rozrodzie dzikich kotowatych zachęcają do kontynuacji badań na kocie domowym w celu doskonalenia procedur i przezwyciężania napotkanych ograniczeń.

\section{PIŚMIENNICTWO}

1. Betteridge K, Rieger D (1993) Embryo transfer and related techniques in domestic animals, and their implications for human medicine. Hum Reprod 8: 147-167

2. Andrabi SMH, Maxwell WMC (2007) A review on reproductive biotechnologies for conservation of endangered mammalian species. Anim Reprod Sci 99: 223-243

3. IUCN 2021 The IUCN Red List of Threatened Species. Version 20212. http://www.iucnredlist.org. Downloaded on 11 September 2021. www.iucnredlist.org.

4. Myers N, Mittermeier R, Mittermeier CG, da Fonseca G, Kent J (2000) Biodiversity hotspots for conservation priorities. Nature 403: 853-858

5. Comizzoli P, Songsasen N, Wildt DE (2010) Protecting and Extending Fertility for Females of Wild and Endangered Mammals 156: 87-100

6. Pukazhenthi B, Wildt D, Howard J (2001) The phenomenon and significance of teratospermia in felids. J Reprod Fertil 57: 423-33

7. Ringleb J, Waurich R, Wibbelt G, Streich W, Jewgenow K (2011) Prolonged storage of epididymal spermatozoa does not affect their capacity to fertilise in vitro matured domestic cat (Felis catus) oocytes when using ICSI. Reprod Fertil Dev 23: 1-8

8. Chang M (1959) Fertilization of rabbit ova in vitro. Nature 184: 466-467

9. Comizzoli P, Crosier a E, Songsasen N, Gunther MS, Howard JG, Wildt DE (2009) Advances in reproductive science for wild carnivore conservation. Reprod Domest Anim 44 Suppl 2: 47-52

10. Wildt D (2009) Rescuing endangered animals with assisted reproductive technology. Sex Reprod Menopause 7: 21-25

11. Wisely SM, Santymire RM, Livieri TM, Marinari PE, Kreeger JS, Wildt DE et al. (2005) Environment influences morphology and develop- ment for in situ and ex situ populations of the black-footed ferret (Mustela nigripes). Anim Conserv 8: 321-328

12. Swanson WF (2003) Research in nondomestic species: experiences in reproductive physiology research for conservation of endangered felids. ILAR J 44: 307-316

13. Pope C (2000) Embryo technology in conservation efforts for endangered felids. Theriogenology 55: 163-174

14. Williams VL, Loveridge AJ, Newton DJ, Macdonald DW (2017) A roaring trade? The legal trade in Panthera leo bones from Africa to East-Southeast Asia. PLoS One 12: 1-22

15. Gratwicke B, Mills J, Dutton A, Gabriel G, Long B, Seidensticker J, et al. (2008) Attitudes toward consumption and conservation of tigers in China. PLoS One 3: 1-7

16. Wildt DE, Roth TL (1997) Assisted reproduction for managing and conserving threatened felids. 35: 164-172

17. Wildt DE (2000) Genome resource banking for wildlife research, management, and conservation. Ilar J 41: 228-234

18. Jewgenow K, Zahmel J (2020) Preservation of female genetic resources in feline species. Theriogenology 156: 124-129

19. Müller K, Eder S, Jakop U, Schiller J, Müller P, Bashawat M (2020) Assisted reproduction for felid species conservation - Sperm competences at risk. Reprod Domest Anim 55: 55-60

20. Swanson WF (2006) Application of assisted reproduction for population management in felids: the potential and reality for conservation of small cats. Theriogenology 66: 49-58

21. Luvoni GC (2006) Gamete cryopreservation in the domestic cat. Theriogenology 66: 101-111

22. Haskins M, Aguirre G, Jezyk P, Patterson D (1980) The pathology of the feline model of mucopolysaccharidosis VI. Am J Pathol 101: 657674

23. Haskins M, Aguirre G, Jezyk P, Patterson D (1983) The pathology of the feline model of mucopolysaccharidosis I. Am J Pathol 112: 27-36

24. Kauppinen R, Chang A, Cevario S, O'Brien S, Haskins M, Desnick R (1994) Feline porphyria and isolation of the feline cDNA for hydroxymethylbilane synthase. Am J Hum Gene 55

25. Jones T (1969) Sex chromosome anomaly, Klinefelter's syndrome. Comp Path Bull 1

26. Pelican KM, Wildt DE, Pukazhenthi B, Howard J (2006) Ovarian control for assisted reproduction in the domestic cat and wild felids. Theriogenology 66: 37-48

27. Biggers JD (2012) IVF and embryo transfer: historical origin and development. Reprod Biomed Online 25: 118-127

28. Schriver M, Kraemer D (1978) Embryo transfer in the domestic feline. Am Assoc Lab Anim Sci Publ 12

29. Goodrowe KL, Walker SL, Ryckman DP, Mastromonaco GF, Hay M, Bateman HL, et al. (2000) Piecing together the puzzle of carnivore reproduction. Anim Reprod Sci 60-61: 389-403

30. Dresser BL, Gelwicks EJ, Wachs KB, Keller GL (1988) First successful transfer of cryopreserved feline (Felis catus) embryos resulting in live offspring. J Exp Zool 246: 180-186

31. Nizański W, Mikołajewska N, Partyka A, Ochota M (2012) Biotechniki w rozrodzie kotowatych - stan wiedzy, perspektywy i wyzwania. Med Weter 68: 529-533

32. Kochan J, Niżański W, Moreira N, Cubas ZS, Nowak A, Prochowska $S$, et al. (2020) ARTs in wild felid conservation programmes in Poland and in the world. J Vet Res 63: 457-464

33. Zambelli D, Cunto M (2005) Transcervical artificial insemination in the cat. Theriogenology 64: 698-705

34. Brown JL (2006) Comparative endocrinology of domestic and nondomestic felids. Theriogenology 66: 25-36

35. Howard JG, Wildt DE (2009) Approaches and efficacy of artificial insemination in felids and mustelids. Theriogenology 71: 130-148

36. Zambelli D, Bini C, Cunto M (2015) Endoscopic transcervical catheterization in the domestic cat. Reprod Domest Anim 50: 13-16 
37. Luvoni GC, Colombo M (2020) Cold case: Small animal gametes cryobanking. Theriogenology 150: 445-451

38. Swanson WF, Roth TL, Godke RA (1996) Persistence of the developmental block of in vitro fertilized domestic cat embryos to temporal variations in culture conditions. Mol Reprod Dev 43: 298-305

39. Swanson WF (2018) Practical application of laparoscopic oviductal artificial insemination for the propagation of domestic cats and wild felids. Reprod Fertil Dev 31: 27-39

40. Mikołajewska N, Müller K, Niżański W, Jewgenow K (2012) Vitrification of domestic cat oocytes - effect on viability and integrity of subcellular structures. Reprod Domest Anim 47 Suppl 6:295-299

41. Wood TC, Wildt DE (1997) Effect of the quality of the cumulus - oocytecomplex in the domestic cat on the ability of oocytes to mature, fertilize and develop into blastocysts in vitro. J Reprod Fertil 110: 355-360

42. Luvoni GC, Chigioni S (2006) Culture strategies for maturation of carnivore oocytes. Theriogenology 66: 1471-1475

43. Sowińska N, Frankowska K, Filipczyk A, Adamaszek A, Nalik K, Fic K, Fulbiszewska A (2016) The effect of cumulus cells on domestic cat (Felis catus ) oocytes during in vitro maturation and fertilization. Reprod Domest Anim 51: 1-6

44. Colombo M, Alkali IM, Prochowska S, Luvoni GC (2021) Fighting like cats and dogs: Challenges in domestic carnivore oocyte development and promises of innovative culture systems. Animals 11: 2135

45. Goodrowe K, Wall R, O'Brien S, Schmidt P, Wildt D (1988) Developmental competence of domestic cat follicular oocytes after fertilization in vitro. Biol Reprod 39: 355-372

46. Pope CE, Johnson CA, McRae MA, Keller GL, Dresser BL (1998) Development of embryos produced by intracytoplasmic sperm injection of cat oocytes. Anim Reprod Sci 53: 221-236

47. Sowińska N, Zahmel J, Niżański W, Hribal R, Fernandez-Gonzalez L, Jewgenow K (2020) Meiotic status does not affect the vitrification effectiveness of domestic cat oocytes. Animals 10: 1-13

48. Pope C, Keller G, Dresser (1993) In vitro fertilization in domestic and non-domestic cats including sequences of early nuclear events, development in vitro, cryopreservation and successful intra- and interspecies embryo transfer. J Reprod Fertil Suppl 47: 189-201.

49. Pope CE, Schmid R, Dresser BL (1999) In vitro development of cat embryos produced by in vitro fertilization is enhanced by addition of cysteine to the maturation medium and a reduced $\mathrm{O} 2$ atmosphere. Theriogenology 51: 291

50. Hoffert KA, Anderson GB, Wildt DE, Roth TL (1997) Transition from maternal to embryonic control of development in IVM/IVF domestic cat embryos. Mol Reprod Dev 48: 208-215

51. Camous S, Heyman Y, Méziou W, Ménézo Y (1984) Cleavage beyond the block stage and survival after transfer of early bovine embryos cultured with trophoblastic vesicles. J Reprod Fertil 72: 479-485

52. Roth TL, Swanson WF, Wildt DE (1994) Developmental competence of domestic cat embryos fertilized in vivo versus in vitro. Biol Reprod. 51: 441-451

53. Johnston L, Donoghue A, O'Brien S, Wildt D (1991) Influence of temperature and gas atmosphere on in-vitro fertilization and embryo development in domestic cats J Reprod Fertil 92: 377-382

54. Johnston L, Donoghue A, O'Brien S, Wildt D (1991) Culture medium and protein supplementation influence in vitro fertilization and embryo development in the domestic cat. J Exp Zool 257: 350-359

55. Filliers M, Rijsselaere T, Bossaert P, Zambelli D, Anastasi P, Hoogewijs $\mathrm{M}$, et al. (2010) In vitro evaluation of fresh sperm quality in tomcats: a comparison of two collection techniques. Theriogenology 74: 31-39

56. Zambelli D, Prati F, Cunto M, Iacono E, Merlo B (2008) Quality and in vitro fertilizing ability of cryopreserved cat spermatozoa obtained by urethral catheterization after medetomidine administration. Theriogenology 69: 485-490
57. Swanson WF, Bateman HL, Vansandt LM (2017) Urethral catheterization and sperm vitrification for simplified semen banking in felids. Reprod Domest Anim 52: 255-260

58. Hassan HA, Domain G, Luvoni GC, Chaaya R, Van Soom A, Wydooghe E (2021) Canine and feline epididymal semen - a plentiful source of gametes. Animals 11: 1-10

59. Swanson WF (2003) Research in nondomestic species: experiences in reproductive physiology research for conservation of endangered felids. ILAR J 44: 307-316

60. Pope CE, Gómez MC, Dresser BL (2006) In vitro production and transfer of cat embryos in the 21st century. Theriogenology 66: 59-71

61. Swanson W, Brown J (2002) Reproductive biotechnology and international training programs for the conservation of Brazilian felids. Proc Meet Am Assoc Zoo Vet 2: 205-207

62. Swanson W, Bond J, Steinetz B, McRae M (2001) Fetal and neonatal development of domestic cats produced from in vitro fertilization and laparoscopic oviductal embryo transfer versus natural mating. Theriogenology 55: 371

63. Pope C, McRae M, Plair B, Keller G, Dresser B (1994) Successful in vitro and in vivo development of in vitro fertilized two- to four-cell cat embryos following cryopreservation, culture and transfer. Theriogenology 42 : $513-525$

64. Pope CE, Gomez MC, Dresser BL (2006) In vitro embryo production and embryo transfer in domestic and non-domestic cats. Theriogenology 66: 1518-1524

65. Swanson W, McRae M, Wildt D, Rall W (1999) Cryoprotectant toxicity and cryopreservation success in IVF-derived domestic cat embryos after embryo transfer. Theriogenology 51: 174

66. Swanson W, McRae M, Bond J, Melniczek J, Haskens M (2000) Homozygous and heterozygous mucopolysaccharidosis kittens produced by transfer of frozen-thawed IVF embryos. Biol Reprod. 62 Suppl 1: 319

67. Luvoni G, Pellizzari P, Battocchio M (1997) Effects of slow and ultrarapid freezing on morphology and resumption of meiosis in immature cat oocytes. J Reprod Fertil Suppl 51: 93-98

68. Pope CE, Gómez MC, Kagawa N, Kuwayama M, Leibo SP, Dresser BL (2012) In vivo survival of domestic cat oocytes after vitrification, intracytoplasmic sperm injection and embryo transfer. Theriogenology 77: 531-538

69. Cocchia N, Ciani F, Russo M, El Rass R, Rosapane I, Avallone L, et al (2010) Immature cat oocyte vitrification in open pulled straws (OPSs) using a cryoprotectant mixture. Cryobiology 60: 229-234

70. Comizzoli P, Wildt DE, Pukazhenthi BS (2003) Overcoming poor in vitro nuclear maturation and developmental competence of domestic cat oocytes during the non-breeding season. Reproduction 126: 809-816

71. Merlo B, Iacono E, Regazzini M, Zambelli D (2008) Cat blastocysts produced in vitro from oocytes vitrified using the cryoloop technique and cryopreserved electroejaculated semen. Theriogenology. 70: 126-130

72. Murakami M, Otoi T, Karja NWK, Wongsrikeao P, Agung B, Suzuki $\mathrm{T}$ (2004) Blastocysts derived from in vitro-fertilized cat oocytes after vitrification and dilution with sucrose. Cryobiology 48: 341-348

73. Tharasanit T, Manee-In S, Buarpung S, Chatdarong K, Lohachit C, Techakumphu M (2011) Successful pregnancy following transfer of feline embryos derived from vitrified immature cat oocytes using "stepwise" cryoprotectant exposure technique. Theriogenology 76: 1442-1449

74. Guraya S. A histochemical analysis of lipid yolk deposition in the oocytes of cat and dog (1965) J Exp Zool 160: 123-135

75. Buranaamnuay K (2017) Protocols for sperm cryopreservation in the domestic cat: A review. Anim Reprod Sci 183: 56-65 


\section{The domestic cat as a research model in the assisted reproduction procedures of wild felids}

\section{Natalia Sowińska ${ }^{\otimes}$}

Animal Reproduction Unit, Department of Genetics and Animal Breeding, Faculty of Veterinary Medicine and Animal Science, Poznan University of Life Sciences PULS

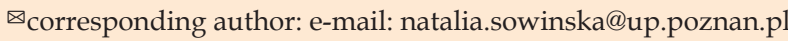

Keywords: biotechnics, in vitro fertilization, embryo transfer, cryopreservation, oocytes, embryos

\section{SUMMARY}

The assisted reproduction techniques are an essential part of endangered species conservation programs. All wild felids are threatened with extinction, and the domestic cat is a good and easily available model for research on wild felids. The procedures used in cats and wild felids include artificial insemination, oocytes collection from female and sperm collection from male, in vitro maturation of oocytes, in vitro fertilization by IVF and ICSI, embryo culture, embryo transfer, cryopreservation of gametes and embryos. The effectiveness of individual procedures in cats and wild felids is often much lower than in humans, livestock or laboratory animals, but the success achieved so far confirms the need for further research.
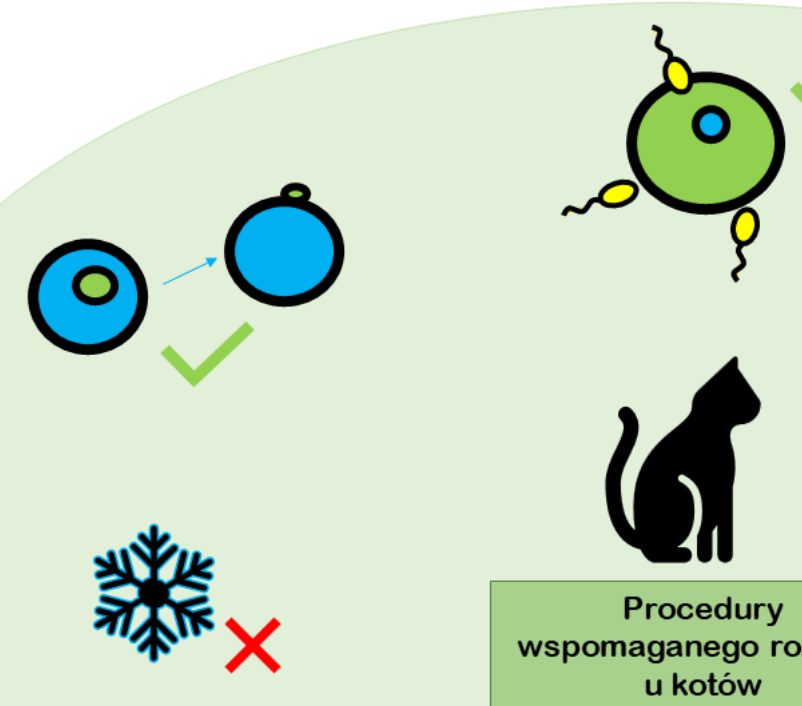

Procedury wspomaganego rozrodu u kotów

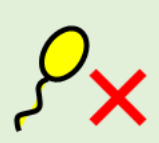

